\title{
Analisis Perputaran Piutang Dalam Meningkatkan Modal Kerja Pada PT. Kereta Api Indonesia (Persero) Divre I Sumatera Utara
}

\author{
Henny Andriyani Wirananda ${ }^{1)}$ \& Purwita Sari ${ }^{2)}$ \\ ${ }^{1)}$ Universitas Muslim Nusantara Al-Washliyah, email : hennyandriyani@umnaw.ac.id \\ ${ }^{2)}$ Universitas Potensi Utama, email : spurwitha@gmail.com
}

\section{ARTICLES INFORMATION}

ABSTRACT

\section{JURNAL SEKURITAS \\ (Saham, Ekonomi, Keuangan, dan Investasi) \\ Vol.3, No.2, Januari 2020 Halaman : 148-157 \\ (c) LPPM \& Prodi Manajemen Universitas Pamulang \\ ISSN (online) : 2581-2777 ISSN (print) : 2581-2696}

\section{Keyword : \\ Perputaran Piutang, Modal Kerja, Aktiva Lancar, Hutang Lancar.}

JEL. classification :

C33, G21, G24, N15, N25

\section{Contact Author : \\ PRODI MANAJEMEN UNPAM \\ JL.Surya Kencana No.1 \\ Pamulang Tangerang Selatan - Banten \\ Telp. (021) 7412566, Fax (021) 7412491 Email : \\ sekuritas@unpam.ac.id}

Penelitian ini bertujuan untuk mengetahui bagaimana perputarab piutang dalam meningkatkan modal kerja pada PT. Kereta Api Indonesia (Persero) Divre I Sumatera Utara. Penelitian ini merupakan penggambaran tentang hasil yang diperoleh dalam penelitian yang terdiri atas variabel penelitian. Teknik analisis data yang digunakan dalam penelitian ini meliputi analisis deskriptif.

Hasil penelitian ini menunjukan peningkatan perputaran piutang karena pelunasan piutang yang cepat tertagih. Penyebab tidak tercapainya peningkatan modal kerja pada perusahaan PT. Kereta Api Indonesia (Persero) Divre I Sumatera Utara karena penurunan aktiva lancar dan hutang lancar pada tahun yang sama. Maka hasil penelitian ini tidak sesuai dengan teori keown et al "Bahwa apabila perputaran piutang dalam suatu perusahaan selama satu periode tertentu berjalan dengan lancar dan cepat dinilai dengan kas, maka tingkat modal kerja juga meningkat".

This study aims to find out how accounts receivable turnover in increasing working capital at PT. Kereta Api Indonesia (Persero) Divre I of North Sumatra. This research is a description of the result obtained in a study consisting of research variables. Data analysis techniques used in this study include descriptive analysis.

The results of this study indicate an increase in accounts receivable. The cause of not achieving an increase in working capital at the company PT. Kereta Api Indonesia (Persero) Divre I North Sumatra due to a decrease in current assets and current debt in the same year. So the results of this study are not in accordance with the theory of Keown et al. 


\section{A. PENDAHULUAN}

Piutang merupakan elemen modal kerja yang juga selalu dalam keadaan berputar secara terus menerus dalam rantai perputaran modal kerja, semakin besar jumlah piutang suatu perusahaan, maka semakin besar resiko tetapi sejalan dengan itu dapat memperbesar profitabilitas menurut Bambang Riyanto (2001 : 85). Modal kerja merupakan hal yang sangat penting yang harus diperhatikan karena menyangkut pengadaan barang dan jasa untuk dijual yang akan menjadi pendapatan dan laba. Modal kerja adalah dana yang dipergunakan untuk melangsungkan kegiatan operasional perusahaan sehari-hari. Dalam setiap aktivitas perusahaan selalu memerlukan dana untuk membiayai dan membelanjakan kegiatan operasinal perusahaan sehari-hari.

Piutang terjadi dikarenakan perusahaan melakukan transaksi penjualan barang dan jasa secara kredit. Piutang meliputi semua tagihan utang yang dilakukan perorangan badan usaha atau pihak lain. Proses pemberian piutang dimulai dari tahap pengambilan keputusan memberikan kredit kepada customer, dilanjut kepada tahap melakukan pengiriman barang, dan tahap terakhir melakukan penagihan dan menerima pembayaran atas transaksi piutang. Piutang dapat dijadikan menjadi kas dengan segera dimana jangka waktu pinjaman paling lama satu tahun. Namun realita dilapangan sering terjadi penagihan piutang yang tidak tepat waktu dari waktu yang sudah ditetapkan, disamping itu perusahaan juga memerlukan dana secara kas untuk diputar dalam membiayai aktivitas operasional perusahaan sehari-hari dan memenuhi kewajiban lancar perusahaan tepat pada waktunya. Semakin tinggi keuntungan piutang maka dapat diterima pada waktunya dan dapat dijadikan jaminan atas pembayaran kas yang sudah dijadwalkan pihak terkait. Seberapa cepat piutang dikonversikan menjadi kas merupakan kebijakan perusahaan dengan menghitung perputaran piutang.

Menurut kasmir (2014 : 250) "Modal kerja adalah modal yang digunakan untuk melakukan kegiatan operasi perusahaan. Dan sebagai investasi yang ditanamkan dalam aktiva lancar atau aktiva jangka pendek seperti : kas, bank, surat berharga, piutang, persediaan, dan aktiva lancar lainnya. Masalah permodalan merupakan masalah yang sering terjadi yang akan berdampak kepada kegiatan operasional perusahaan yang terjadi. Modal yang digunakan untuk kegiatan usaha ini disebut modal kerja. Modal kerja adalah harta yang dimiliki perusahaan yang dipergunakan untuk menyelenggarakan kegiatan operasional sehari-hari perusahaan yang selalu berputar dalam periode tertentu. Yang termasuk dalam komponen modal kerja adalah kas, piutang, dan persediaan yang merupakan bagian dari aktiva perusahaan.

Untuk dapat mengetahui jumlah modal kerja yang dibutuhkan suatu perusahaan, dapat dilakukan analisis terhadap modal kerja dengan berpedoman pada informasi dan laporan keuangan suatu perusahaan. Pendapatan dan laba merupakan salah satu unsur dalam modal kerja dalam meningkatkan dan mengembangkan usaha perusahaan. Dalam beberapa kasus diketahui bahwa turunnya modal kerja akan menurunkan efektifitas modal kerja untuk kebutuhan aktifitas operasional dengan demikian dapat dilihat kemampuan suatu perusahaan untuk memperoleh pendapatan dan laba (Keuntungan) akan berkurang.

Perbandingan laporan keuangan perputaran piutang dan modal kerja selama periode 5 tahun terakhir yang telah dihitung. Dengan menggunakan tabel perputaran piutang dan tingkat modal kerja pada PT. Kereta Api Indonesia (Persero) Divre I Sumatera Utara adalah sebagai berikut : 
Tabel 1.1

Tabel Perputaran Piutang dan Tingkat Modal Kerja PT. Kereta Api Indonesia (Persero) Divre I Sumatera Utara Tahun 2012 - 2016

\begin{tabular}{|c|c|c|c|}
\hline No & Tahun & $\begin{array}{c}\text { Perputaran Piutang } \\
(\text { kali })\end{array}$ & Modal Kerja \\
\hline 1 & 2012 & 13,7 & 567.279 .875 .561 \\
\hline 2 & 2013 & 14,6 & 1.968 .020 .936 \\
\hline 3 & 2014 & 18,9 & 4.313 .636 .563 \\
\hline 4 & 2015 & 24,7 & 583.714 .027 .632 \\
\hline 5 & 2016 & 24,1 & 662.056 .404 .603 \\
\hline
\end{tabular}

Sumber : Laporan keuangan (laba/rugi dan neraca) tahun 2012 - 2016 PT. Kereta Api Indonesia (Persero) Divre I Sumatera Utara.

Berdasarkan tabel diatas maka dapat diketahui bahwa terdapat fenomena yang terjadi pada PT. Kereta Api Indonesia (Persero) Divre I, perputaran piutang mengalami peningkatan dari tahun 2012-2016. Pada tahun 2013 perputaran piutang mengalami peningkatan namun modal kerja mengalami penurunan sebesar 1.968.020.936 hal ini bertentangan dengan teori (keown et al, 2001 : 157) "Bahwa apabila perputaran piutang dalam suatu periode tertentu berjalan lancar dan cepat dinilai dengan kas maka tingkat modal kerja juga meningkat". Begitu juga menurut Munawir (2004) keadaan perputaran piutang yang tinggi menunjukkan bahwa efisien dan efektif perusahaan mengelola piutang. Penurunan modal kerja terjadi tahun 2013 sangat beresiko apabila dikaitkan dengan ketersediaan kebutuhan dana bagi pemenuhan aktifitas perusahaan, kekurangan modal kerja yang terus menerus akan menghambat terlaksananya suatu kegiatan perusahaan, naik turunnya perputaran piutang akan mempengaruhi modal kerja suatu perusahaan.

Perusahaan ini menggunakan perputaran piutang modal kerja yang berasal dari hasil laba pada tahun sebelumnya sehingga aktifitas operasional tahun sekarang akan mempengaruhi tahun yang akan datang. Setiap peningkatan akan penjualan dan pendapatan tahun sekarang maka semakin efektif tingkat modal kerja perusahaan yang digunakan pada tahun yang akan datang. Oleh karena itu ukuran modal kerja dalam hal ini dapat diukur dengan melihat seberapa besar perputaran piutang dapat dengan cepat mendukung modal kerja perusahaan.

Bagi perusahaan PT. Kereta Api Indonesia (Persero) Divre I Sumatera Utara modal kerja yang efektif sangat diperlukan dalam mendukung kepentingan kelangsungan operasional perusahaan yang akan membutuhkan modal kerja yang sangat banyak.

Berdasarkan uraian diatas, maka penulis tertarik untuk meneliti dengan judul "Analisis Perputaran Piutang Dalam Meningkatkan Modal Kerja Pada PT. Kereta Api Indonesia (Persero) Divre I Sumatera Utara".

Dari latar belakang, maka peneliti merumuskan masalah sebagai berikut :

1) Mengapa terjadi penurunan modal kerja ditahun 2013 pada PT. Kereta Api Indonesia (Persero) Divre I Sumatera Utara?

2) Bagaimana Perputaran piutang dalam meningkatkan Modal Kerja pada PT. Kereta Api Indonesia (Persero) Divre I Sumatera Utara?

\section{B. TINJAUAN PUSTAKA}

\section{Perputaran Piutang}

Piutang merupakan elemen penting dalam modal kerja selalu dalam keadaan berputar. Artinya piutang akan tertagih pada saat tertentu dan akan muncul kembali akibat transaksi penjualan secara kredit. Tingkat perputaran piutang tergantung dari syarat pembayaran yang diberikan kepada perusahaan. Semakin lama syarat 
pembayaran semakin lama dana atau modal terikat dalam piutang, yang berarti semakin rendah tingkat perputaran piutang.

Menurut Munawir (2004 : 75) mengatakan bahwa "posisi piutang dan taksiran waktu pengumpulannya, dapat dinilai dengan menghitung tingkat perputaran piutang (Turn Over Recaivable) yaitu dengan membagi total penjualan kredit (neto) dengan piutang rata-rata".

Rasio perputaran piutang ini mengungkapkan efektifitas sebuah perusahaan dalam pemberian dan penagihan kredit. Pemberian kredit pada pelanggan dengan resiko kredit yang buruk dapat menyebabkan penagihan yang tidak efektif sehingga menghasilkan rasio perputaran piutang yang rendah. Rasio yang sangar rendah merupakan suatu indikasi masalah, karena kemungkinan bagian kredit perusahaan dan bagian penagihan piutang bekerja tidak efektif sehingga perusahaan mengalami over investment dalam piutangnya.

Namun rasio yang sangat tinggi juga dapat dijadikan indikasi masalah, karena kemungkinan adanya kebijakan kredit perusahaan terlalu ketat, sehingga dapat menyebabkan perusahaan kehilangan penjualan dan laba. Seperti halnya yang dikemukakan oleh Munawir (2007 : 5) bahwa "makin tinggi rasio (Turn Over) menunjukan modal kerja yang ditanamkan dalam piutang rendah, sebaliknya jika rasio semakin rendah berarti ada over kredit dan penagihan bekerja tidak efektif atau mungkin ada perubahan dalam kebijaksanaan pemberian kredit".

\section{Faktor-faktor yang mempengaruhi perputaran piutang}

Perputaran piutang dipengaruhi oleh 2 faktor : penjualan kredit dan rata-rata piutang. Beberapa faktor yang menyebabkan terjadinya penurunan pada rasio penjualan kredit dan rata-rata menurut Munawir (2007 : 25) adalah :

1. Turunnya Penjualan dan naiknya piutang

2. Turunnya piutang dan turunnya penjualan dalam jumlah lebih besar

3. Naiknya penjualan dan naiknya piutang dalam jumlah yang besar

4. Turunnya penjualan dengan piutang tetap

5. Naiknya piutang sedangkan penjualan tidak berubah

\section{Modal Kerja}

Dalam menjalankan kegiatan operasional sehari-hari, perusahaan membutuhkan modal kerja di dalamnya guna membelanjai setiap kegiatan perusahaan yang terkait langsung dengan kegiatan operasi perusahaan, seperti : membeli bahan baku, membayar gaji buruh, membayar hutang-hutang perusahaan. Dengan sejumlah yang dikeluarkan untuk kegiatan operasional dengan harapan akan mendapatkan kembali laba pada perusahaan dalam jangka waktu pendek.

Menurut Gito Sudarmo dan Basri (2002 : 33) "Modal kerja merupakan kekayaan atau aktiva yang diperlukan oleh perusahaan untuk menyelenggarakan kegiatan seharihari yang selalu berputar dalam periode tertentu."

Menurut Agnes Sawir (2005: 129) "Modal Kerja adalah sebagai dana yang harus tersedia untuk membiayai kegiatan operasi perusahaan sehari-hari".

\section{Jenis-jenis Modal Kerja}

Dermawan Syahrial (2007 : 122) yang diungkapkan oleh W.B Taylor ada beberapa dapat digolongkan menjadi :

1. Modal kerja permanen : modal kerja primer dan modal kerja normal

2. Modal kerja variabel : modal kerja musiman, modal kerja siklis, dan modal kerja darurat. 


\section{Unsur-unsur Modal Kerja}

1. Aktiva Lancar

Menurut Munawir (2013: 14) aktiva lancar adalah uang kas dan aktiva lainnya yang dapat diharapkan untuk dicairkan atau ditukarkan menjadi uang tunai, dijual atau dikonsumsi dalam periode berikutnya dalam jangka waktu satu tahun atau kurang melalui operasi normal perusahaan. Sedangkan menurut Ais Zakiyudin (2015 : 32) mengemukakan bahwa "aktiva lancar adalah uang tunai dan aktiva lain yang dapat diluangkan tidak lebih dari satu tahun. Dari definisi diatas dapat disimpulkan bahwa aktiva lancar terdiri dari kas dan bank, surat-surat berharga, piutang dan persediaan.

2. Hutang Lancar

Menurut Munawir (2013 : 18), hutang lancar atau hutang jangka pendek adalah kewajiban keuangan perusahaan yang pelunasannya atau pembayarannya akan dilakukan dalam jangka pendek (satu tahun sejak tanggal neraca) dengan menggunakan aktiva lancar yang dimiliki oleh perusahaan hutang lancar terdiri dari hutang dagang, hutang jangka panjang yang jatuh tempo, hutang deviden, biaya yang masih harus dibayar, dan penghasilan yang diterima dimuka.

\section{Faktor- Faktor yang Mempengaruhi Jumlah Modal Kerja}

Bagi perusahaan jumlah modal kerja yang ada akan sangat diperlukan perusahaan, untuk menentukan jumlah modal kerja yang diperlukan oleh suatu perusahaan terdapat beberapa faktor didalamnya.

Menurut Munawir (2007 : 69), faktor-faktor yang mempengaruhi modal kerja adalah sebagai berikut :

1. Sifat umum atau jenis perusahaan

2. Waktu yang diperlukan untuk memproduksi atau mendapatkan barang dan ongkos produksi per unit atau harga beli per unit barang

3. Syarat pembelian dan penjualan

4. Tingkat perputaran persediaan

5. Tingkat perputaran piutang

6. Pengaruh konjungtur

7. Derajat risiko

8. Pengaruh musim

\section{METODE PENELITIAN}

\section{Jenis Penelitian}

Metode penelitian yang digunakan adalah menggunakan pendekatan deskriptif. Pendekatan deskriptif adalah pendekatan dengan menggunakan satu atau lebih variabel guna menjelaskan variabel mandiri

\section{Sumber Data}

Dalam penelitian ini menggunakan sumber data sekunder yaitu data diperoleh langsung dari sumbernya. Data sekunder dari penelitian ini diperoleh dari bagian akuntansi PT. Kereta Api Indonesia (Persero) Divre I Sumatera Utara berupa data tertulis yaitu dokumentasi yang terdiri dari laporan keuangan perusahaan.

\section{Teknik Pengumpulan Data}

Teknik pengumpulan data dalam penelitian ini adalah studi dokumentasi yaitu teknik pengumpulan data dengan cara melihat dan mempelajari dokumen perusahaan melalui pengumpulan informasi yang bersumber dari laporan keuangan PT. Kereta Api Indonesia (Persero) Divre I Sumatera Utara.

\section{Teknik Analisis Data}

Teknik analisa data menggunakan metode deskriptif pendekatan akuntansi yang merupakan metode yang digunakan dengan merumuskan perhatian terhadap pemecahan masalah yang dihadapi, dimana data-data tersebut :

- Mengumpulkan data 
- Mengelola data

- Menganalisis data

- Diinterprestasikan

\section{HASIL DAN PEMBAHASAN}

\section{Hasil Penelitian}

Hasil penelitian dan pembahasan merupakan penggambaran tentang hasil yang diperoleh dalam penelitian yang terdiri atas variabel penelitian. Dalam penelitian ini juga termasuk data atas keterangan yang terkait dengan laporan keuangan.

Data yang diperoleh merupakan kondisi keuangan PT. Kereta API Indonesia (Persero) Divre I Sumatera Utara dari tahun 2012 - 2016. Data ini diperoleh dari laporan keuangan dalam bentuk neraca dan laporan laba rugi.

Sesuai dengan perumusan masalah model yang telah dikemukakan, maka teknik analisis data yang digunakan dalam penelitian ini meliputi analaisis deskriptif. Analisis deskriptif merupakan analisis yang mengacu pada deskriptif kondisi perusahaan.

\section{Perputaran Piutang}

Berdasarkan data laba/rugi dan neraca yang disajikan perusahaan, maka perlu diketahui besarnya perputaran piutang perusahaan. Perputaran piutang adalah rasio yang membandingkan antara jumlah penjualan kredit dibagi dengan jumlah ratarata piutang selama periode satu tahun. Sedangkan di PT. Kereta Api Indonesia (persero) Divre I Sumatera Utara menghitung perputaran piutang dengan jumlah pendapatan usaha dibagi jumlah rata-rata piutang.

Berdasarkan tabel perputaran piutang pada PT. Kereta Api Indonesia (Persero) Divre I Sumatera Utara tahun 2012-2016 sebagai berikut :

\section{Tabel IV.1}

Perputaran Piutang PT. Kereta Api Indonesia (Persero) Divre I Sumatera Utara Periode 2012-2016

\begin{tabular}{|c|c|c|c|}
\hline Tahun & Pendapatan & Rata-Rata Piutang & $\begin{array}{c}\text { Perputaran } \\
\text { Piutang (Kali) }\end{array}$ \\
\hline 2012 & 939.865 .452 .237 & 68.567 .147 .069 & 13,7 \\
\hline 2013 & 988.428 .977 .876 & 67.281 .513 .836 & 14,6 \\
\hline 2014 & 1.163 .630 .554 .090 & 61.285 .449 .764 & 18,9 \\
\hline 2015 & 1.561 .006 .423 .717 & 63.023 .627 .119 & 24,7 \\
\hline 2016 & 1.893 .989 .492 .513 & 78.430 .572 .918 & 24,1 \\
\hline
\end{tabular}

Sumber laporan keuangan PT. Kereta Api Indonesia (persero) Divre I Sumatera Utara

Dari tabel diatas menunjukan pendapatan berasal dari kegiatan utama perusahaan disebut pendapatan usaha dimana setiap tahunnya pendapatan perusahaan terus meningkat dari tahun 2012-2016 peningkatan jumlah aktiva atau penurunan kewajiban dapat berasal dari penyerahan jasa atau aktivitas usaha lainnya dalam suatu periode. Peningkatam jumlah aktiva dapat berbentuk diterimanya uang tunai, timbulnya piutang atau aktiva lainnya.

Rata-rata piutang pada tabel diatas menunjukkan pada tahun 2012-2014 mengalami penurunan kemudian pada tahun 2015-2016 mengalami peningkatan. Rata-rata piutang berasal dari penjumlahan piutang awal periode dan piutang akhir periode dibagi dua dan piutang perusahaan berasal dari piutang yang timbul dari jasajasa yang dihasilkan perusahaan.

Perputaran piutang pada table diatas menunjukkan dari tahun 2012-2016 mengalami peningkatan, perputaran piutang berasal dari pendapatan dibagi dengan rata-rata piutang. Peputaran piutang pada perusahaan dilihat pada tabel bahwa 
menggambarkan kualitas piutang perusahaan dan kesuksesan perusahaan dalam penagihan yang dimilikinya karena mengalami peningkatan setiap tahunnya.

\section{MODAL KERJA}

Modal kerja digunakan untuk membiayai operasi perusahaan sehari-hari, dimana dana yang telah dikeluarkan diharapkan akan kembali dalam jangka waktu yang relatif pendek melalui aktifitas perusahaan yang akan dipergunakan untuk kegiatan operasi selanjutnya. Pada penelitian ini modal kerja dilihat dari perhitungan yaitu modal kerja bersih (netto) dengan rumus : Aktiva Lancar (Current Asset) dikurangi dengan kewajiban Lancar (Current Liabilities). Modal kerja bersih suatu perusahaan setelah dikurangi dengan kewajiban lancarnya.

Unsur utama modal kerja adalah aktiva lancar dan hutang lancar. Pengelola modal kerja berarti pengelolaan hutang lancar, karena biasanya aktiva lancar dikaitkan dengan hutang lancar. Oleh karena itu dalam memahami pengertian yang sebelumnya aktiva lancar merupakan kas atau sumber yang akan menjadi kas, nilai aktiva lancar ditunjukkan oleh sirkulasi diantara beberapa rekening neraca.

\section{Pembahasan}

Dalam menganalisa laporan keuangan perusahaan, penulis mencoba menganalisa hasil perhitungan perputaran piutang dan modal kerja perusahaan, dimana perputaran piutang dan modal kerja akan dapat memberikan atau menjelaskan gambaran kepada penganlisa tentang efisien atau tidak efisiennya perusahaan dalam menggunakan assetnya untuk memperoleh pendapatan dan laba yang diharapkan, kemudian memberikan gambaran tentang bagaimana perputaran piutang perusahaan dapat meningkatkan modal kerja.

\section{a. Analisis Perputaran Piutang}

Terjadinya peningkatan perputaran piutang disebabkan piutang yang tertagih dengan cepat. Periode perputaran tergantung dari panjang pendeknya ketentuan waktu yang dipersyaratkan dalam syarat pembayaran kredit, sehingga semakin lama syarat pembayaran kredit berarti semakin lama terikatnya modal dalam piutang, maka perputaran piutang dalam satu periode semakin tinggi.

Berdasarkan tabel diatas terjadi peningkatan perputaran piutang pada tahun 2012-2016. Menurut Munawir (2004) keadaan perputaran piutang yang tinggi menunjukkan bahwa efisien dan efektif perusahaan mengelola piutang. Apabila perputaran piutang meningkat maka baik untuk perusahaan karena dapat melunasi piutangnya yang akan kembali menjadi kas. Sedangkan penurunan piutang menyebabkan perusahaan tidak dapat melunasi piutang dengan cepat karena kas tidak akan kembali dengan efisien. Sedangkan jika tingkat perputaran piutang semakin tinggi, maka piutang dapat tertagih dengan cepat dan sebaliknya.

\section{b. Analisis Modal Kerja}

Dari analisis yang telah dilakukan oleh penulis terhadap perhitungan laporan keuangan dengan menggunakan konsep modal kerja bersih maka menggambarkan aktiva lancar setelah dikurangi hutang lancar. Berikut ini data modal kerja PT. Kereta Api Indonesia (persero) Divre I Sumatera Utara tahun 2012-2016 :

Tabel IV.2

Modal Kerja PT.Kereta Api Indonesia (Persero) Divre I Sumatera Utara Periode 2012-2016

\begin{tabular}{|c|c|c|c|}
\hline Tahun & Aktiva Lancar & Hutang Lancar & Modal Kerja \\
\hline 2012 & 765.513 .518 .919 & 198.233 .643 .358 & 567.279 .875 .561 \\
\hline 2013 & 490.691 .402 .990 & 488.723 .382 .054 & 1.968 .020 .936 \\
\hline 2014 & 600.296 .676 .222 & 595.983 .039 .659 & 4.313 .636 .563 \\
\hline
\end{tabular}


$2015-1.125 .589 .415 .358$ \begin{tabular}{|l|l}
1.125 .589 .415 .358 & 541.875 .387 .726
\end{tabular} 541.875.387.726 583.714 .027 .632

$2016 \quad 1.274 .053 .559 .663$ 611.997.155.060 662.056 .404 .603

Sumber : Laporan Keuangan tahun 2012-2016 PT. Kereta Api Indonesia (persero) Divre I

Pada tahun 2012 modal kerja perusahaan mengalami peningkatan, hal ini dikarenakan adanya peningkatan jumlah aktiva lancar, hutang lancarnya mengalamin penurunan, sedangkan tahun 2012 aktiva lancar dan hutang lancar perusahaan mengalami penurunan. Namun tahun 2014 - 2016 aktiva daan hutang lancar perusahaan mengalami peningkatan.

Berdasarkan penjelasan diatas bahwa tidak sesuai dengan teori yang sudah dikemukakan oleh keown et al (2001:157) "bahwa apabila perputaran piutang dalam suatu perusahaan dalam suatu periode tertentu berjalan lancar dan cepat dinilai dengan kas maka tingkat modal kerja juga meningkat.

Penurunan modal kerja sangat beresiko apabila dikaitkan dengan ketersediaan kebutuhan dana bagi pemenuhan aktivitas perusahaan, kekurangan modal kerja yang terus - menerus dapat menghambat kelancaran kegiatan perusahaan dalam membiayai dan membelanjai kegiatan operasional perusahaan. Modal kerja yang menurun berdampak pada kegiatan operasional perusahaan sehari-hari dan berdampak pada laba operasional perusahaan. Rendahnya modal kerja yang dimiliki perusahaan memungkinkan kegiatan operasi perusahaan dapat terganggu. Modal kerja pada perusahaan ini menurunkarena biaya usaha yang terus meningkat setiap tahunnya ditahun 2012-2013 tidak diikuti dengan kenaikan aktiva lancarnya. Modal kerja perusahaan dari tahun ketahun mengalamin perkembangan yang berfluktuasi, sedangkan perputaran piutang meningkat setiap tahunnya. Modal kerja yang meningkat dan menurun disebabkan oleh berbagai berbagai unsur modal kerja (kas, piutang, persediaan dan surat-surat berharga). Tersediannya modal kerja yang segera dapat dipergunakan dalam operasi tergantung pada type atau sifat dari aktiva lancar yang dimiliki perusahaan.

Terjadinya penurunan modal kerja disebabkan pada penurunan aktiva lancar diiringin dengan penurunan hutang lancar yang signifikan ditahun yang sama cukup besar sehingga menyebabkan modal kerja menurun. Aktiva lancar yang turun disebabkan kaena pembelian persediaan setiap tahunnya sehingga mengalami penurunan pada kas perusahaan yang cukup besar. Penurunan modal kerja yang terjadi pada perusahaan dilihat dari koponen kas yang menurun setiap tahunnya, kas menurun dapat menyebabkan modal kerja tidak dapat efisien dalam membiayai dan membelanjai kegiatan operasionalnya. Terjadi penurunan pada aktiva lancar juga disebabkan pada biaya usaha yang meningkat setiap tahunnya tidak diikuti dengan peningkatan aktiva lancar. Keburukan manajemen aktiva lancar dan hutang lancar dapat mengakibatkan kegagalan perusahaan. Bertambahnya aktiva lancar harus diimbangi dengan hutang lancar.

\section{a. Analisis Perputaran Piutang Dalam Meningkatkan Modal Kerja}

Perputaran piutang yang tinggi menunjukkan cepatnya pengembalian dana yang tertanam dalam piutang menjadi kas kembali. Pelunasan piutang dapat digunakan kembali untuk penjualan kredit atau pemberian pinjaman kembali. Kembalinya kas karena pelunasan piutang sangat menguntungkan perusahaan karena kas akan selalu tersedia dan dapat digunakan kembali sehingga operasional dan keuangan perusahaan tidak terganggu dalam melakukan kegiatan operasional perusahaan.

Tetapi modal kerja harus cukup jumlahnya dalam artian harus mampu membiayai dan membelanjai pengeluaran-pengeluaran atau operasi perusahaan seharihari, karena dengan modal kerja yang cukup kan menguntungkan bagi perusahaan. Disamping memungkinkan bagi perusahaan untuk beroperasi secara ekonomis atau efisien dan perusahaan tidak mengalami kesulitan keuangan, tetapi juga akan memberikan keuntungan. Modal kerja bersih yang ada diperusahaan merupakan salah satu indikator untuk menilai perusahaan dalam kemampuan membayar semua kewajiban finansial jangka pendeknya. 
Hasil penelitian ini tidak sesuai denga teori keown et al "bahwa apabila perputaran piutang dalam suatu perusahaan selama satu periode tertentu berjalan dengan lancar dan cepat dinilai dengan kas, maka tingkat modal kerja juga meningkat". Kemudian hasil penelitian ini juga didukung hasil penelitian krisna (2013) dan Rinny Rizky Amalia Siregar (2013) yang membuktikan bahwa meningkatnya perputaran piutang maka modal kerja juga meningkat.

Modal kerja didalam perusahaan akan terus berputar dan selalu dalam keadaan beroperasi selama perusahaan yang bersangkutan dalam keadaan menjalankan usahanya. Sebaliknya perusahaan dapat mengetahui jumlah modal kerja yang dibutuhkan sehingga perusahaan tidak mengalami kesulitan keuangan dan memperoleh keuntungan. Naik dan turunnya perputaran piutang akan mempengaruhi modal kerja perusahaan dimana turunnya perpututaran piutang akan menurunkan modal kerja perusahaan, sebaliknya apabila perputaran piutang meningkat maka akan mengingkat juga modal kerjanya.

Semakin tinggi tingkat perputaran piutang maka semakin tinggi tingkat modal kerja perusahaan. Semakin tinggi modal kerja maka akan semakin efisiensi perusahaan dalam melakukan kegiatan dalam membiayai dan membelanjai kegiatan operasional perusahaan sehari-hari. Dengan menghitung tingkat perputaran piutang dapat diketahui beberapa kali piutang tertagih selama satu periode tertentu dan mengkonfersikannya menjadi kas yang akan digunakan perusahaan untuk melunasi kewajiban jangka pendeknya pada saat jatuh tempo sehingga modal kerja dapat meningkat.

\section{E. KESIMPULAN}

Berdasarkan hasil penelitian diperusahaan PT. Kereta Api Indonesia (Persero) Divre I Sumatera Utara dan hasil analisis yang dilakukan pada uraian teoritis pada bab sebelumnya, maka penulis dapat mengambil beberapa kesimpulan sebegai berikut :

1. Terjadinya peningkatan perputaran piutang yang terjadi pada tahun 2012-2016. Dengan adanya peningkatan perputaran piutang maka modal kerja juga akan meningkat, sebaliknya jika terjadi penurunan pada perputaran piutang maka modal kerja juga akan terjadi penurunan.

2. Selama periode tahun 2012- 2013 cenderung terjadi penurunan yang cukup tinggi. Namun walaupun begitu modal kerja perusahaan masih dapat dikatakan baik karena modal kerja yang berlebihan jika tidak dipergunakan untuk kegiatan operasianal juga tidak ada manfaatnya bagi PT. Kereta Api Indonesia (Persero) Divre I Sumatera Utara.

3. Terjadinya peningkatan perputaran piutang disebabkan oleh pelunasan piutang yang cepat tertagih. Sedangkan tidak tercapainya peningkatan modal kerja pada perusahaan disebabkan oleh adanya penurunan antara aktiva lancar dan hutang lancar yang terjadi pada tahun yang sama. Walaupun perusahaan modal kerjanya mengalami penurunan yang cukup tinggi tetapi perusahaan sudah berusaha untuk meningkatkan modal kerjanya.

\section{DAFTAR PUSTAKA}

Abdul Kadim, K., Nardi Sunardi, S., Hendro Waryanto, W., Dessy Adelin, A., \& Endang Kusmana, K. (2018). The Effects Of Bank Soundness With The RGEC Approach (Risk Profile, Good Corporate Governance, Earnings, Capital) Of Leverage And Its Implications On Company's Value Of State Bank In Indonesia For The Period Of 20122016. IJER (International Journal of Economic Research), 15(11), 41-52.

Agnes Sawir. (2005), Analisa Kinerja Keungan Dan Perencanaan Keuangan Perusahaan, Cetakan Kelima. Jakarta: Gramedia Pustaka Utama 
Ais Zakiyudin. (2013), Akuntansi Tingkat Dasar Jakarta : Mitra Wacana Media

Bambang Riyanto. (2008), Dasar-Dasar Pembelanjaan Perusahaan, Edisi Keempat. Yogyakarta : BPEG

Dermawan Sjahrial. (2007), Pengantar Manajemen Keuangan, Edisi Ketiga. Jakarta : Mitra Wacana Media

Ikatan Akuntan Indonesia. (2009), Standar Akuntansi Keuangan. Jakarta : Salemba Empat

Jumingan. (2007), Analisis Laporan Keuangan. Jakarta : PT. Bumi Aksara

Kadim, A., \& Sunardi, N. (2019). Pengaruh Profitabilitas, Ukuran Perusahaan Terhadap Leverage Implikasi Terhadap Nilai Perusahaan Cosmetics and Household yang terdaftar di Bursa Efek Indonesia. Jurnal SEKURITAS (Saham, Ekonomi, Keuangan dan Investasi), 3(1), 22-32.

Kasmir. (2012), Analisis Laporan Keuangan, Edisi Pertama, Cetakan Kedua. Jakarta : PT.Raja Grafindo Persada

Krisna. (2010), Pengaruh Perputaran Piutang dan Perputaran Persediaan Terhadap Modal Kerja, Studi Kasus Pada Industry Barang Konsumsi di Bursa Efek Jakarta. Semarang Fakultas Ekonomi Negeri Semarang.

Muhammad Rifandi (2013), Pengaruh Perputaran Persediaan Terhadap Modal Kerja Pada Perusahaan Makanan Dan Minuman Yang Terdaftar Di Bursa Efek Indonesia (BEI), Skripsi, Jurusan Akuntansi, Fakultas Ekonomi, Universitas Muhammadiyah Sumatera Utara.

Munawir. (2007), Analisa Laporan Keuangan, Edisi Keempat. Yogyakarta : liberty

Rinny Risky Amalia Siregar. (2013), Analisis Perputaran Piutang Dalam Meningkatkan Modal Kerja Pada PT.Angkas Pura II (Persero) Bandara Polonia Medan, Skripsi, Jurusan Akuntansi, Fakultas Ekonomi, Universitas Muhammadiyah Sumatera Utara.

Soemarso. (2004), Akuntansi Suatu Pengantar, Edisi Kelima, Jakarta : Salemba Empat

Sunardi, N. (2017). Determinan Kebijakan Utang Serta Implikasinya terhadap Kinerja Perusahaan (Perusahaan yang tergabung dalam indeks LQ. 45 yang terdaftar di Bursa Efek Indonesia Tahun 2011-2015). Jurnal Sekuritas, 1(1).

Sunardi, N. (2018). Analisis Du Pont System Dengan Time Series Approach (Tsa) Dan Cross Sectional Approach (Csa) Dalam Penilaian Kinerja Keuangan Perusahaan (Studi Pada Industri Konstruksi (BUMN) di Indonesia Yang Listing di BEI Tahun 20132017). Jurnal SEKURITAS (Saham, Ekonomi, Keuangan dan Investasi), 1(4).

Werner R.Murhadi. (2013), Analisa Laporan Keuangan Proyeksi Dan Valuasi Saham, Jakarta : Salemba Empat. 